\title{
A MÍSTICA EM ALGUMAS FORMAS DE MANIFESTAÇÕES RELIGIOSAS ${ }^{1}$
}

Raymundo Heraldo Maués ${ }^{2}$

Resumo: Discuto um aspecto das várias manifestaçóes religiosas que têm sido pesquisadas no Brasil, que é a mística e, mais especificamente - em meu caso particular -, na Amazônia Oriental. A mística está presente em todas as formas de religião, mas restrinjo estas reflexóes a determinados cultos e igrejas. Começo tratando de cultos xamânicos que estudei mais particularmente numa parte da Amazônia brasileira, passando em seguida ao importante fenômeno do pentecostalismo, que estudei, por vários anos, no âmbito da Arquidiocese de Belém, através da Renovação Carismática Católica. Analiso ainda a mística das aparições marianas, a presença da mística de matriz africana e, também, no xamanismo urbano, em algumas manifestaçóes da nova era, bem como a mística das plantas e de outras substâncias de poder. Estes últimos tópicos, com base na literatura disponível. Todas essas questóes serão discutidas tendo como pano de fundo teórico a temática da secularização, do desencantamento do mundo e, também, de um possível reencantamento, em que as igrejas estabelecidas perdem seus adeptos, enquanto outras formas religiosas se mantêm ou se multiplicam.

Palavras-chave: Mística; Xamanismo; Catolicismo; Religiōes de matriz africana; Nova era.

1 Artigo apresentado no GT 21 - A religiāo, novos e antigos contornos: repensando teorias, métodos e formas de classificação, durante as XVII Jornadas sobre Alternativas Religiosas na América Latina, realizadas no período de 11 a 14 de novembro de 2013, na cidade de Porto Alegre/RS, Brasil. Agradeço aos coordenadores do GT, Cecília Loreto Mariz (UERJ/Brasil), Paulo Gracino Junior (IUPERJ/Brasil) e Cesar Ceriani (UBA e FLACSO) pela aceitação da proposta. Agradeço à colega Kátia Marly Leite Mendonça, da UFPA, pela leitura prévia e pelas sugestóes valiosas de revisão do texto inicial. Agradeço ainda os comentários e as questóes formulados pelos integrantes do GT, quando de sua apresentação, bem como aos pareceristas anônimos, que me ajudaram a reformular este texto para publicação.

2 Universidade Federal do Pará. Bolsista de Produtividade do CNPq.

Contato: hmaues@uol.com.br

Debates do NER, Porto Alegre, ano I5, N. 26, P. I93-227, JUl./DeZ. 2014 
Abstract: I discuss an aspect of the various religious manifestations that have been researched in Brazil, that is, the mystique and, more specifically - in my particular case -, in Eastern Amazonia. The mystique is present in all forms of religion, but I restrict these reflections to certain churches and cults. I start treating of shamanic cults that I have studied more particularly in a part of the Brazilian Amazon, passing then to the important phenomenon of Pentecostalism, which I studied for several years, under the Archdiocese of Belém, through the Catholic Charismatic Renewal. I analyze the mystique of Marian Apparitions, the presence of mysticism in the religions of African array and, also, in the urban shamanism, and in some manifestations of the new era. Well as in the mystique of plants and other power substances. These latter topics, based on the available anthropological literature. All of these issues will be discussed against the background of the theoretical theme of secularization, the disenchantment of the world and also a possible re-enchantment, where established churches lose their supporters, while other religious forms persist or multiply.

Keywords: Mysticism; Shamanism; Catholicism; Religions of African array; New era.

\section{INTRODUÇĀO: A MÍSTICA NA TRADIÇĀO WEBERIANA}

Inicialmente devemos considerar a distinção entre os conceitos de misticismo e ascese. $\mathrm{O}$ primeiro envolve uma relação de proximidade às (ou intimidade com as) entidades sobrenaturais, enquanto a segunda se refere ao comportamento disciplinado, tal como se apresenta, por exemplo, na tão conhecida ética protestante (de inspiração calvinista). Que, segundo Weber, associada à ideia de vocação (beruf, celebrizada inicialmente por Lutero) possui afinidade eletiva com o espirito do capitalismo que, como é sabido, não se confunde com o que esse sociólogo denomina pela expressão latina auri sacra fames (sagrada fome do dinheiro).

Não se trata aí principalmente de utilizar tipos ideais como instrumentos heurísticos (embora também em outro contexto possam sê-lo), mas de conceitos distintos - tão fundamentais na consideração sociológica do fenômeno religioso - e não contraditórios se encarados em determinadas 
situações. A invocação a tipos ideais nessa condição tem a ver com as formas, regras e disciplinas de exercer a religião, como através das igrejas, das seitas ou da mistica (neste último caso, levando em conta a influência de um dos membros do círculo weberiano - Troelstch - como é bem conhecido). Tratase também, nestes três tipos, de diferentes manifestaçóes do "carisma" (num sentido mais amplo), um deles (igreja) de alguma forma banalizado e sob forte controle dos sacerdotes, outro (seita) com um tipo de carisma exacerbado (em diferentes graus, mas nunca desencantado) e com forte liderança de algum profeta; e, finalmente, um terceiro tipo, em que o carisma está também fortemente presente (a mística), mas não necessariamente em um líder que conduza intensamente seus seguidores, pois aqui a relação com a entidade sobrenatural é de grande proximidade, a ponto de muitas vezes até mesmo prescindir de liderança humana forte ou carismática, já que nem sempre se manifesta através de alguma forma de organização. Por isso, mais importante ainda, neste terceiro tipo ideal, não se trata necessariamente de criar nova denominação (seja seita ou igreja) independente, pois ela pode estar presente dentro de seitas ou - principalmente - de igrejas, implicando até o trânsito sem necessariamente um compromisso mais firme entre igrejas e seitas diferentes ${ }^{3}$.

Um dos exemplos de organização em que podem se abrigar diferentes tipos de mística, que podem também se manifestar com a estrutura de seitas, será o da Igreja Católica Apostólica Romana (ICAR). A ICAR, não tendendo tão facilmente à cisão ou fragmentação, produzindo novas igrejas, costuma conter em seu seio diferentes tendências, movimentos, congregaçóes (pode-se aqui falar em formas de diversidade também abrigadas sob o manto

3 Estas questóes aparecem em Weber, sobretudo na Ética Protestante e no capítulo sobre sociologia da religião em Economia e Sociedade, mas também em alguns artigos. Quanto ao livro de Troelstch, que trata da mística em sua obra mais importante intitulada Die Soziallerhren der Christlichen Kirchen und Gruppen, até onde posso saber, não está traduzido para o português. Utilizo aqui o artigo de Fortunato Mallimaci intitulado Ernest Troelstch y la Sociologia Histórica del Cristianismo, publicado na revista Sociedad y Religión (Werber, 2004a; 2004b; Mallimaci, 1987).

Debates do NER, Porto Alegre, ANo I5, N. 26, P. 193-227, JUl./DEZ. 2014 
de Maria), o que a torna extremamente complexa. Como disse certa vez um importante antropólogo brasileiro (embora nascido na França), Pierre Sanchis, ela pode ser simbolizada pela condição de um pêndulo: tudo aquilo que cabe na movimentação do pêndulo, à direita e à esquerda, cabe nessa totalidade. Diferentemente do que acontece no protestantismo que, acrescento eu - mas inspirado parcialmente por feliz observação de Rubem César Fernandes -, como no caso dos Nuer, povo africano estudado pelo conhecido antropólogo britânico Evans-Pritchard, tende sempre a se fragmentar em diferentes linhagens ou seitas (seitas das quais podem também resultar novas igrejas).

Tomemos, no caso do catolicismo, dois exemplos de místicos famosos: Santa Tereza d'Ávila e São Francisco de Assis. Este, pertencente ao medievo, não foi o único a fundar ordem mendicante, mas esteve - como outros - numa espécie de balança, da qual só escapou por ter ousado se dirigir pessoalmente ao Papa e ter recebido (contra outras perspectivas possíveis) a autorização para sua empresa (o ramo inicial da ordem franciscana, que mais tarde se fragmentou em numerosas outras congregaçóes e denominaçôes, algumas delas condenadas como hereges). Curiosamente, a despeito de sua iniciativa ousada de fundar uma das mais importantes ordens mendicantes medievais, mais tarde, quase no final da vida, por não possuir capacidade administrativa adequada nem conseguir redigir uma regra de caráter mais utilitário, viu-se guindado à posição decorativa e simbólica, enquanto a administração de sua ordem passou para mãos mais habilitadas e práticas para exercer o comando ${ }^{4}$. Quanto à Madre Tereza, mística dos princípios da

4 Como diz Victor Turner, em seu livro O Processo Ritual: "É interessante observar que, vários anos antes de sua morte, $\mathrm{S}$. Francisco tinha abandonado o governo da Ordem e passava grande parte do tempo em companhia de um pequeno grupo de companheiros em eremitérios na Úmbria e na Toscana. Sendo um homem de relaçóes diretas e imediatas, a 'communitas' para ele deveria ser sempre concreta e espontânea. É possível que tenha ficado desalentado com o sucesso do seu próprio movimento, que começara, já durante a sua vida, a dar sinais da estruturação e rotinização que iria sofrer sob a influência de sucessivos 'gerais' e sob a força configuradora externa de uma série de bulas papais". É também o mesmo autor que nos esclarece sobre sua sucessão: “O próprio primeiro sucessor

Debates do NER, Porto Alegre, ano I5, N. 26, P. I93-227, JUl./DeZ. 20 I4 
Idade Moderna, época em que se desenvolvia o mercantilismo, a partir do impulso já ocorrido na Idade Média feudal com o surgimento da burguesia e o desenvolvimento do comércio, temos também um momento de grave tensão em que seu texto famoso (La Vida) precisou ser examinado pelos inquisidores. Mas acabou sendo autorizado, tornando-se obra prima da literatura universal. Essa mulher, entretanto, tinha personalidade forte que, apesar de sua debilidade física, aliava a isso atividade tão intensa no processo de moralização que exerceu na Espanha sobre as ordens monásticas femininas. Como carmelita, desempenhou papel importante nessa ordem, começando em 1560 sua importante obra de reforma do Carmelo. Era, portanto, ao mesmo tempo mística e ascética, uma tendência não anulando a outra, permitindo-lhe importância excepcional no panteão dos santos da ICAR, tendo sido a primeira Doutora da Igreja 5 .

de S. Francisco, Elias, foi o que Lambert chama 'figura essencialmente organizadora que, em tantas sociedades religiosas, traduziu os sublimes ideais de seus fundadores em termos aceitáveis para os discípulos que vieram depois' (p. 74). É significativo dizer que foi Elias a força propulsora oculta atrás da construção da grande basílica de Assis, para abrigar o corpo de S. Francisco, e cujos bons ofícios levaram a municipalidade de Assis em 1937 a erigir-lhe um monumento. Segundo Lambert, 'ele deu uma contribuição mais duradoura ao desenvolvimento da cidade do que à evolução do ideal franciscano' (p. 74). Com Elias, a estrutura, tanto material quanto abstrata, começou a substituir a "communitas" (Turner 1974, p. 181).

5 Suas obras mais famosas foram La Vida e Las Moradas. No primeiro há seu texto místico mais conhecido e polêmico, que aqui transcrevo parcialmente: "Quiso el Señor que viese aquí algunas veces esta visión: vía un ángel cabe mi hacia el lado izquierdo en forma corporal, lo que no suelo ver sino por maravilla [...]. Víale en las manos un dardo de oro, largo, y al fin de el hierro me parecía tener un poco de fuego. Este me parecía meter por el corazón algunas veces, y que me llegaba a las entrañas. Al sacarle, me parecía las llevaba consigo, y me dejaba toda abrasada en amor grande de Dios. Era tan grande el dolor, que me hacia dar aquellos quejidos, y tan ecesiva la suavidad que me pone este grandísimo dolor, que no hay que desear que le quite, ni se contenta el alma con menos que Dios. No es dolor corporal, sino espiritual, aunque no deja de participar el cuerpo algo, y an harto. Es un requiebro tan suave que pasa entre el alma y Dios, que suplico 
Não devemos, porém, levar em conta somente os grandes místicos da história universal, e não somente no cristianismo, mas também em várias outras tradiçôes e organizaçôes religiosas, como o budismo, o hinduísmo, o islā, o judaísmo e várias outras, por menos importantes que pareçam ser. Começaremos por tratar de espécie tão espalhada e antiga de misticismo que, ao invés de poder ser considerada arcaica, como a chamou Eliade (1998), deve ser considerada contemporânea e quiçá destinada a viver por longos e longos anos: o xamanismo. Esse exame, correspondendo à extensa pesquisa que desenvolvi há vários anos, refere-se mais especificamente à pajelança cabocla na Amazônia Oriental brasileira.

\section{UMA FORMA DE CULTO XAMÂNICO NA AMAZÔNIA BRASILEIRA}

Em primeiro lugar, deve ser lembrado que essa forma de xamanismo não se confunde com as práticas xamânicas das diferentes populaçóes indígenas amazônicas, tanto no Brasil como em naçóes limítrofes que possuem parte de seu território na chamada Pan-Amazônia. Os estudos iniciais sobre esse culto são antecipados por denúncias encontradas no Livro da Visitação do Santo Ofício ao Grão Pará, descoberto por acaso na Torre do Tombo, publicado e comentado pelo historiador Amaral Lapa (1978). A Visitação ocorreu no período de 1763 a 1769, logo após a expulsão dos jesuítas de Portugal e de todas as suas colônias, sob a direção do inquisidor Giraldo José de Abranches.

Uma das primeiras ações desse personagem ao chegar em Belém foi cumprir a ordem de prisão do bispo, D. Frei João de São José e Queiroz, que ficou em Portugal aprisionado num convento, até a morte ${ }^{6}$. Na prisão,

yo a su bondad lo dé a gustar a quien pensare que miento" (Teresa de Jesus, 1995, p. 1887-188).

6 Sobre ele existe a seguinte notícia na internet, no Portal da Arquidiocese de Belém:

"Nasceu em Matosinhos, próximo à cidade do Porto, Portugal, a 12 de agosto de 1711. 
ele continuou a redação de suas memórias das visitas pastorais, livro que constitui importante fonte para o conhecimento da Amazônia colonial e, ao mesmo tempo, indica parcialmente as razões da prisão do bispo que, rigoroso com os desmandos do clero, era ao mesmo tempo um homem esclarecido e além de sua época que, entre suas ações, mandou liberar do Aljube (prisão eclesiástica) da cidade de Belém do Grão Pará uma mulher acusada de "familiaridade com o diabo", por ter tido um ataque de eclampsia, confundido na época de sua prisão com possessão demoníaca (Almeida Pinto, 1906, p. 70). Esse ato (a prisão do bispo) permitiu também que o inquisidor assumisse a função de secretário geral da diocese e, consequentemente, acumulasse as funçôes exercidas pelo bispo, aumentando seus poderes.

Outra ação do inquisidor, assim que se instalou no palácio episcopal (antigo Colégio dos Jesuítas de Belém, anexo à imponente igreja barroca de Santo Alexandre), foi a de publicar aviso segundo o qual no prazo de um mês todos aqueles que tivessem confissóes de atos praticados contra as normas eclesiásticas deveriam fazê-lo, ficando, com isso, isentos de qualquer constrangimento ou castigo. Não houve confissões, mas choveram denúncias. Uma das mais denunciadas foi a índia Sabina, importante xamã acusada, entre outras coisas, de curar "feitiço" que tinha sido feito contra um dos governadores do Estado do Grão-Pará e que ela descobriu oculto numa das

Era beneditino. Veio para o Pará em 1760 e aqui passou apenas quatro anos. Criou a paróquia da Vigia e inaugurou a igreja de Sant'ana. Caiu no desagrado do governo português, devido a seus escritos críticos, e, por isso, foi desterrado para Portugal, falecendo no dia 15 de agosto de 1764 no convento de São João de Pendurada, 'mosteiro triste, empinado nuns rochedos que se debruçam sobre o Douro'. Suas visitas pastorais foram escritas num célebre livro prefaciado por Camilo Castelo Branco. Obs.: Com o desterro de Dom João, o bispado ficou sede vacante durante 6 anos". Texto disponível em: http://www.arquidiocesedebelem.org.br/interno/preview_abrir_sub1_noticia. php? categoriaid $=5 \&$ linkid $=36 \&$ sub $1 \mathrm{id}=11 \&$ noticiaid $=10 \&$ estilo_link=0. Acesso em: 30 jul. 2013. Essas informaçóes podem ser facilmente combinadas com aquilo que nos diz Amaral Lapa na apresentação que escreveu sobre o Livro da Inquisição (Amaral Lapa, 1978, p. 30, p. 55-56; Queiroz, 1961; Ramos, 1952, p. 25). 
paredes de pedra e cal do Palácio do Governo. Além disso, algumas denúncias registradas no Livro da Inquisição descrevem sessões religiosas semelhantes ao que atualmente encontramos no xamanismo indígena ou caboclo, inclusive com a utilização de elemento ritual importante, o cigarro "taquari" (tauari) ${ }^{7}$.

Mas os primeiros estudos sobre aquilo que denomino de pajelança cabocla foram feitos por folcloristas, a partir do século XIX. A dissertação de mestrado, mais tarde publicada em livro, do historiador Aldrin de Moura Figueiredo, conta-nos essa história: buscando investigar e analisar a constituição do campo de estudos sobre pajelança cabocla na Amazônia, Figueiredo vai buscar as notas e a bibliografia utilizada por Eduardo Galvão em seu livro Santos e Visagens (Galvão, 1955). Esses folcloristas são os pioneiros em que se inspirou Galvão para traçar o mapa da pajelança como parte da "religião do caboclo amazônico". Há todo um mapa cognitivo construído por esses personagens, que constitui um conjunto de crenças e práticas em que estão mescladas antigas tradiçôes de origem tupi, com elementos fundamentais do catolicismo de fontes ibéricas e medievais trazido pelos portugueses e, também, alguns traços de concepções e práticas de raiz africana, bem como traços nos quais se pode notar em anos mais recentes uma leve ou mais acentuada influência kardecista. Não se trata, evidentemente, de uma igreja ou seita: é um culto xamânico que possui, sobretudo, finalidades terapêuticas.

O xamá caboclo, curador ou mais raramente surjāo da terra, considerase um bom católico, como observei em minhas pesquisas, e não considera seu culto como contraditório em relação ao catolicismo popular que pratica. Para ele, as expressóes pajelança ou pajé não são utilizadas comumente, a não ser o termo pajé, que não se refere a ele, mas aos outros, sobretudo quando deles deseja falar mal. Nas sessóes de culto, recebe seus guias ou caruanas, que não são pensados como espíritos, mas como encantados, isto é, seres humanos especiais - muitos deles príncipes ou princesas, atestando uma influência portuguesa; índios ou caboclos; e, mais raramente, negros - que não morreram, mas se encantaram, vivendo em lugares chamados de encantes.

7 Todo este relato baseia-se na obra do historiador Amaral Lapa (1978) acima referida. 
Estas são moradas que existem no fundo da terra ou das águas (muitas delas na superfície são ilhas encantadas, cheias de pedras e/ou belas praias do mar, também com muitas pedras). Algumas dessas pedras são mesmo identificadas com encantados bem conhecidos, entre eles o famoso Rei Sabá (D. Sebastiāo, antigo rei português que desapareceu durante a batalha de Alcácer-Quibir, no século XVI; é considerado o mais importante encantado do litoral dos estados do Pará e Maranhão, também cultuado nas religiōes de matriz africana).

Durante o trabalho ou sessão xamanística, o pajé ou curador incorpora, uma a uma, diversas entidades (encantadas) que são chamadas de "caruanas" nessa ocasião, porque se manifestam de forma invisível. Existem duas outras formas de manifestação, quando suas denominações são diferentes: "bichos do fundo", ao aparecerem sob a forma de animais aquáticos (botos, peixes, cobras, jacarés); "Oiaras" (Iaras, forma portuguesa mais difundida), quando surgem como figuras humanas, de ambos os sexos, nas praias e nos mangais (manguezais) buscando atrair pessoas comuns para seus lugares de morada (encantes); e "encantados da mata" (Anhangas e Curupiras) que podem também se manifestar como caruanas, incorporando-se raramente nas sessóes xamanísticas, mas que mais frequentemente exercem uma espécie de controle nas florestas, castigando os caçadores que cometem abusos contra os animais ${ }^{8}$.

É nesse "trabalho" que o curador trata de seus pacientes, utilizando diferentes técnicas corporais, dançando e cantando, fumando o cigarro tauari (com que defuma seus consulentes) e receitando banhos especiais e remédios. A principal técnica curativa é a incorporação de entidades que, segundo a crença, são aquelas que efetivamente curam ou receitam remédios para os pacientes do pajé. Mas este também pode se comunicar com seus caruanas de forma mais direta, em casos especiais, não praticando o conhecido voo xamanístico, mas viajando pelo fundo das águas, em que visita a morada dos

8 Este aspecto "ecológico" do culto e das crenças xamânicas das populaçóes rurais e de origem rural da Amazônia não está em contradição com as origens românticas e conservadoras do movimento preservacionista contemporâneo, que encontra raízes na Europa do XIX. 
encantados a fim de aprender novos conhecimentos e técnicas terapêuticas. Nesse caso, corre riscos, pois não deve aceitar os alimentos que ali lhe são oferecidos, sob pena de encantar-se e não mais poder voltar à convivência dos outros seres humanos como ele.

Não é o caso aqui de prolongar esse tema, oferecendo outros detalhes, pois o que me interessa, sobretudo, é acentuar os aspectos místicos da pajelança cabocla que, como toda forma de xamanismo, implica uma aproximação extrema do ser humano com as entidades sobrenaturais (embora no caso os sobrenaturais sejam também pensados como humanos, só que humanos "encantados"). Nessa forma de mística, o xamã está o tempo todo - como acontece com outros xamãs - sendo possuído por suas entidades, que ele também possui, as quais o controlam e são por ele controladas, embora os momentos de êxtase e possessão ocorram somente em ocasióes especiais e programadas. Isso envolve um longo processo de iniciação que implica um aprendizado, geralmente proporcionado por um "mestre", isto é, outro pajé que pode adotá-lo como discípulo. Pode levar mais ou menos tempo, mas culmina com uma cerimônia de iniciação chamada de "encruzamento", em que o novo pajé precisa morrer ritualmente para renascer como xamã. $\mathrm{E}$, a partir daí, seguir vários preceitos, que incluem a obrigação de realizar sessóes xamanísticas periódicas e de se abster de determinados alimentos considerados "reimosos" para seu permanente estado liminar como "sacerdote inspirado" que é.

A condição de curador ou pajé é pensada mais frequentemente como masculina. Existem mulheres xamãs em várias comunidades amazônicas e algumas delas podem ser famosas. A mais conhecida é a senhora Zeneida Lima, residente na cidade de Soure, na ilha do Marajó, autora de livro que é uma espécie de autobiografia, republicado em numerosas ediçōes, mas que também descreve e teoriza a respeito de sua arte (Lima, 2002). Sobre ela existem menções em trabalhos acadêmicos e, mais especificamente, em

9 Excepcionalmente, alguns pajés ou curadores dizem-se formados por seus próprios caruanas, sem precisar do concurso de um mestre.

Debates do NER, Porto Alegre, ano I5, N. 26, P. I93-227, JUl./DeZ. 20 I4 
uma dissertação de mestrado recentemente defendida (Faro, 2012a; 2012b). Em muitas situaçóes, inclusive no caso de Zeneida Lima, essas mulheres vivem uma situação de forte ambiguidade, sendo às vezes pensadas como bruxas ou feiticeiras. Essa situação entretanto parece não ser aplicada a todos os casos, haja vista o trabalho já desenvolvido, também na ilha do Marajó, pela antropóloga Patrícia Cavalcante (Cavalcante, 2008), que estudou várias mulheres xamãs nessa ilha.

\section{O PENTECOSTALISMO CATÓLICO}

O pentecostalismo é manifestação religiosa cristã de caráter místico, na qual se atualiza no presente o episódio descrito no segundo capítulo de Atos dos Apóstolos, com uma diferença: a manifestação mais evidente do processo não se trata de xenolalia ou xenoglossia, mas de fenômeno diferente - embora da mesma natureza -, isto é, a glossolalia. Quando, durante a festa de pentecostes, os discípulos de Jesus receberam os dons do Espírito Santo, conforme o relato bíblico, eles falaram de modo a serem compreendidos nas línguas daqueles que os ouviam, pois, embora falassem em sua língua nativa, cada um ali presente entendia suas palavras em suas próprias línguas ${ }^{10}$. Nos dias de hoje, segundo os testemunhos existentes, o fenômeno da xenolalia ou xenoglossia é relatado bem raramente e quase sempre descrito em relação a pessoas cuja identificação é difícil ou mesmo impossível. Já o fenômeno da

10 "Ficaram todos cheios do Espírito Santo e começaram a falar em outras línguas, conforme o Espírito Santo lhes concedia que falassem [...]. Achavam-se então em Jerusalém judeus piedosos de todas as naçóes que há debaixo do céu [...]. Profundamente impressionados, manifestavam a sua admiração: 'Não são, porventura, galileus todos estes que falam? Como então todos nós os ouvimos falar, cada um em nossa própria língua materna? Partos, medos, elamitas; os que habitam a Mesopotâmia, a Judéia, a Capadócia, o Ponto, a Ásia, a Frígia, a Panfília, o Egito e as províncias da Líbia próximas a Cirene; peregrinos romanos, judeus ou prosélitos, cretenses e árabes; ouvimo-los publicar em nossas línguas as maravilhas de Deus!'” (Atos 2: 4-11; citação da Bíblia publicada pela Editora Ave-Maria, uma das ediçóes mais utilizadas pelos carismáticos que estudei).

Debates do NER, Porto Alegre, ano I5, N. 26, P. 193-227, JUl./DeZ. 20 I4 
glossolalia é muito fácil de observar nos cultos pentecostais, mas necessita de interpretação por aqueles que têm o dom de entender tal linguagem. Além disso, conforme os estudos desenvolvidos a respeito, tal forma de falar não se restringe a fenômenos de natureza religiosa, mas ocorre também em contextos não místicos ou não religiosos (Lewis, 1999, p. 47-48; Pollak-Eltz, 1999). E, mais que isso, em pelo menos dois estudos recentes, no Brasil, é possível constatar que se trata, nos contextos analisados (Renovação Carismática Católica/RCC e Igreja do Evangelho Quadrangular/IEQ), de forma de linguagem que, embora sem sentido aparente, possui de fato estrutura linguística, não sendo, portanto, algo aleatório e sem qualquer sentido (Bonfim, 2012, p. 259-287; Baptista, 1989, p. 246-273).

O caráter místico do pentecostalismo tem a ver com a postulação de proximidade radical do crente com a divindade. Tomando como exemplo a Renovação Carismática Católica/RCC, forma de pentecostalismo que estudei por alguns anos, gostaria de acentuar alguns aspectos que marcam esse misticismo. Em primeiro lugar, trata-se de um dos mais importantes entre os Novos Movimentos Eclesiais (NMEs) da ICAR, com caráter internacional, que se espalha por todo o Brasil e se encontra nas grandes cidades e também nas menores, estando presente mesmo em várias pequenas povoaçóes do interior. Ao lado disso, trata-se de movimento conduzido especialmente por leigos, desde sua fundação, nos EUA, que - na versão particular que estudei, mas que não é a única - tende a acentuar bastante a importância e o protagonismo do leigo, tanto em grupos de oração quanto em comunidades que funda, mesmo que no Brasil uma das mais importantes (como a Canção Nova) seja dirigida por sacerdote. Ao lado disso, é um movimento que nem sempre se reconhece como tal, mas que chega a adotar como lema - pelo menos na versão particular que estudei - a expressão que afirma ser "a Igreja em movimento". Assim, mesmo que tivesse, na época de minha pesquisa na arquidiocese de Belém, um sacerdote que a acompanhava, este tinha muito pouca influência sobre a mesma. Isto, aliás, parece ser característica presente pelo menos na maioria dos assim chamados Novos Movimentos Eclesiais (NMEs) da ICAR, diferentemente do que 
ocorria em movimentos eclesiais importantes e mais antigos, tradicionais e modernos, como o Apostolado da Oração (que ainda se mantém) e a Ação Católica (atualmente inexistente).

A complexidade da RCC no Brasil e no mundo é grande, mas desejo acentuar que seus dois elementos fundamentais são os Grupos de Oração (acompanhei mais de um grupo em Belém por alguns anos) e as Comunidades. O Grupo de Oração é normalmente o que atrai mais adeptos, por ser aberto à participação de todos. As Comunidades de Aliança e de Vida são mais discretas, sendo que, em Belém, a mais importante comunidade carismática de origem local chama-se Maira. Mas as mais importantes comunidades carismáticas no Brasil, tendo também caráter internacional, são a Canção Nova (muito conhecida graças a seu canal televisivo) e a Comunidade Shalom, tendo esta também presença física na cidade de Belém. $\mathrm{O}$ que distingue o grupo de oração da comunidade? A comunidade implica um comprometimento mais intenso, conforme o tipo de participação de seus membros. Brenda Carranza, em seu importante estudo sobre a RCC no Brasil, mostra a distinção entre os dois tipos de comunidades carismáticas:

As primeiras [Comunidades de Aliança] consistem num agrupamento de pessoas entre casados, solteiros e solteiras, profissionais que fazem compromissos privados ou votos dos conselhos evangélicos de pobreza, castidade e obediência. Algumas vezes essas comunidades criam grupos mistos nos quais homens $\mathrm{e}$ mulheres, solteiros e casados, partilham de uma moradia comum. As segundas, as comunidades de vida, são grupos com vínculos fortes de autocontrole e comunhão de bens, e buscam reconhecimento canônico em Roma. Às vezes incorporam na sua estrutura religiosos, religiosas e sacerdotes para orientação espiritual [...]. As Comunidades de Aliança distinguem-se das de Vida pela sua fisionomia jurídica, tanto civil quanto canônica, caracterizando-se como entidades de benefício público. É a partir das comunidades de aliança que na RCC criam-se muitas fundações e associações, através das quais é possível 
captar recursos financeiros, nacionais e internacionais e possuir bens imóveis (Carranza, 2000, p. 63). ${ }^{11}$

O grupo de oração é mais livre, podendo ser frequentado por quem o desejar, mesmo que não haja compromisso mais forte com o mesmo. Qualquer um pode entrar e participar, assim como pode deixar de frequentar. Entretanto, à medida que a pessoa participa, seus compromissos podem se tornar maiores e também ser convidada a frequentar o Seminário de Vida no Espírito ou Querigma que, na minha experiência, corresponde a uma reunião de iniciação que dura um fim de semana, em que os neófitos são introduzidos aos conhecimentos e às práticas fundamentais do movimento. Lembro aqui que a palavra querigma se refere tradicionalmente aos sentidos de mensagem, pregação, anúncio ou proclamação e está relacionada à famosa pregação de Jesus Cristo em Nazaré, quando leu na sinagoga uma passagem do livro de Isaías: "O Espírito do Senhor está sobre mim, porque me ungiu; e enviou-me para anunciar a boa nova aos pobres, para sarar os contritos de coração, para anunciar aos cativos a redenção, aos cegos a restauração da vista, para por em liberdade os cativos, para publicar o ano da graça do Senhor" (Lucas 4: 18, 19). Este é o início do ministério de Jesus, logo depois da também famosa "tentação no deserto", durante a qual ele já se encontrava "cheio do Espírito Santo" (Lucas 4: 1, 18, 19).

Segundo Brenda Carranza a "[...] RCC reproduz seu quadro dirigente através dos Seminários de Vida no Espírito (SVES). Esses seminários são organizados para os iniciados na RCC e que aos poucos formar-se-ão, recebendo a denominação de servos" (Carranza, 2000, p. 51, grifo da autora).

${ }^{11}$ Não é o caso aqui de aprofundar esse assunto, por não ser o objeto principal de minha preocupaçáo neste artigo. Refiro no entanto alguns trabalhos que são importantes para o aprofundamento dessa temática: inicialmente, a coletânea sobre "novas comunidades católicas" (Carranza; Mariz; Camurça, 2009), dois dos mais conhecidos livros de Thomas J. Csordas sobre a RCC americana (Csordas, 1994; 1996) e duas teses recentes de doutorado sobre as mais importantes comunidades carismáticas originadas no Brasil: a Comunidade Shalom e a Canção Nova (Nicolau, 2005; Bonfim, 2012). 
A mesma cita em seguida diretriz do Conselho Nacional da RCC no Brasil sobre esses encontros, que é bastante reveladora:

O fiel cristão esclarece que ele não foge do mundo, porém se insere na realidade do mundo para renová-la e iluminá-la através de sua pessoa renovada e iluminada no poder do Espírito Santo. Assim, o cristão se prepara para sua vida familiar, profissional, social, eclesial (Conselho Nacional, 1995, p. 83 Apud Carranza, 2000, p. 51).

Está aqui bem presente a indicação da mística do "carismático" que estabelece sua união visceral com a divindade, mas não para ensimesmar-se, e sim para exercer a prática da evangelização.

Posso dizer de minha própria experiência que, nesse curto período, alguns neófitos podem ser iniciados mais completamente, podendo aprender a "orar em línguas" e/ou passar pelo chamado "repouso no Espírito". Em qualquer desses processos, realiza-se a união mística do iniciado com a divindade, na medida em que a pessoa recebe a chamada "efusão do Espírito", com a qual ganha também seus dons, através de outra forma mais preciosa de batismo, que não é mais o das águas, mas sim o "do Espírito". Realiza-se aí, de modo literal, o ideal cristão do corpo como "morada do Espírito Santo”. O orar em línguas significa a prática da glossolalia, o mais comum dos dons do Espírito. Ela está presente desde os primeiros anos do cristianismo, embora seja de alguma forma reprimida desde cedo ${ }^{12}$. Depois

12 Esta é minha interpretação particular, não como teólogo, mas como simples leitor/ antropólogo. Desejo aqui lembrar que já em Coríntios I Paulo, depois de enumerar os dons do Espírito, ao exaltar a caridade/amor, começa por dizer aos seus interlocutores: "Ainda que eu falasse as línguas dos homens e dos anjos, se não tiver caridade, sou como o bronze que soa, ou como o címbalo que retine". E, mais adiante: "Empenhai-vos em procurar a caridade. Aspirai igualmente aos dons espirituais, mas sobretudo ao de profecia. Aquele que fala em línguas não fala aos homens, senão a Deus: ninguém o entende, pois fala coisas misteriosas, sob a ação do Espírito [...]. Aquele que fala em línguas edifica-se a si mesmo; mas o que profetiza, edifica a assembleia [...]. Quando vos reunis [...] se há quem fala em línguas, não falem senão dois ou três, quando muito, e cada um por

Debates do NER, Porto Alegre, ano I5, N. 26, P. 193-227, JUl./DeZ. 20 I4 
de ter sido escondida por tanto tempo, somente nas versóes mais místicas do cristianismo ela aparece mais tarde, sendo atualizada hoje em dia na prática pentecostal, católica ou protestante.

O repouso no Espírito, que parece ser uma inovação mais recente (do pentecostalismo?), tem poder curativo do corpo e da alma, manifestando-se por uma espécie de êxtase ou transe muito breve, de poucos minutos, em que o fiel, tocado pela divindade, cai ao chão e ali fica como que desacordado, despertando - conforme relatos - com uma sensação de profundo bem-estar. Um "repouso" muito prolongado, com dificuldade para o despertar e sobretudo se manifestar com certa inquietação, ou a emissão por exemplo de sons guturais durante o processo de orar em línguas, pode indicar algo que é interpretado como ação do Inimigo, e não do Divino. Nesse caso, é necessário proceder com cuidado e buscar formas de exorcizar aquele ente intruso. Evidentemente que, em termos weberianos, considerando a mística como união íntima e significativa com entidades sobrenaturais, temos, nos dois casos - quer no autêntico repouso, quer em sua manifestação indesejada pelos carismáticos - duas formas distintas de mística.

Há também no pentecostalismo duas formas distintas de conceber a mística. No pentecostalismo católico (RCC), encontramos uma situação em que o protagonismo leigo se une a certa desvalorização do papel do sacerdote, especialmente se tomarmos por parâmetro a influência deste como a dos antigos "assistentes" da extinta Ação Católica, a quem cabiam as decisóes finais mais importantes, da mesma forma que ainda, de certo modo, pode acontecer atualmente, por exemplo, numa organização bem distinta, como as Comunidades Eclesiais de Base (CEBs). Temos, pois, uma espécie de misticismo leigo - um tanto "perigoso" para a autoridade sacerdotal eclesiástica - o que pode provocar tensóes e conflitos, porque se o leigo tem acesso direto à Divindade (ou ao seu "contrário", o Inimigo), ele de fato pode, em certas situações, dispensar o sacerdote ou mantê-lo e privilegiá-lo (guardadas as proporçóes), na medida em que este se amolda a seus propósitos. Nesse

sua vez, e haja alguém que interprete. Se não houver quem inteprete, fiquem calados na reunião, e falem consigo mesmos e com Deus" (13: 1; 14: 1, 2, 4, 26, 27, 28).

Debates do NER, Porto Alegre, ano I5, N. 26, P. I93-227, JUl./DeZ. 20 I4 
ponto seria interessante lembrar o que diz André Corten, em seu livro Os Pobres e o Espirito Santo, tratando do pentecostalismo no Brasil (sem esquecer também das Comunidades Eclesiais de Base e da Teologia da Libertação):

Três aspectos suscitaram na era cristã os grandes movimentos religiosos. A primeira é a procura de um contato direto com Deus sem mediação do clero [...]. Frequentemente é associado a ela o segundo elemento típico dos grandes movimentos: a reivindicação de um acesso direto à Bíblia [...]. A terceira aspiração é a valorização da pobreza à imagem de Cristo" (Corten, 1996, p. 28).

Eu diria, ampliando um pouco mais a interpretação, que esses três elementos - com as devidas adaptaçóes - aplicam-se não só ao cristianismo, mas a todas as grandes religiōes e igrejas estabelecidas, já que eles são próprios da mística enquanto tipo ideal e tendem - se considerarmos nessa mesma linha o chamado "campo religioso", nos termos de Pierre Bourdieu - a causar perigo a todas elas, por oferecerem uma forma de autonomização do leigo diante do sacerdote, conduzindo ao que este autor chama de "autoconsumo" religioso. Para Bourdieu, citando aqui somente uma pequena passagem de seu próprio texto:

[...] a constituição de um campo religioso acompanha a desapropriação objetiva daqueles que são dele excluídos e que se transformam por essa razão em leigos (ou profanos, no duplo sentido do termo) destituídos do capital religioso (enquanto trabalho simbólico acumulado) e reconhecendo a legitimidade desta apropriação pelo simples fato de que a desconhecem enquanto tal (BOURDIEU, 1974, p. 39, grifos do autor).

Na medida, porém, em que esses leigos ou profanos se aproximam excessivamente da divindade, dos textos sagrados e da pobreza ("evangélica", no caso do cristianismo, mas algo semelhante pode existir em outras grande igrejas), fica certamente em perigo a hegemonia sacerdotal, sobretudo se entre esses mesmos leigos surgem de outro lado profetas e magos, bruxos ou feiticeiros 
(mesmo que sejam também sacerdotes) como concorrentes mais fortes dos sacerdotes tout court (Bourdieu, 1974, p. 39 e passim; Várguez Pasos, 2002).

Daí porque certos sacerdotes, cuja adesão à RCC é muito forte, passam a ser também muito valorizados pelos leigos, que tendem a escolhê-los para suas cerimônias ou rituais e que tendem a lhes dar maior aceitação. Isso pode ser fonte de tensões constantes entre a atuação da RCC e a hierarquia sacerdotal ${ }^{13}$

O mesmo pode não ocorrer - pelo menos de forma tão intensa - no pentecostalismo protestante, em que a distinção entre sacerdotes (pastores) e leigos não precisa ser tão marcante. Não obstante, aqui lidamos com outro tipo de seita - não uma espécie de "seita" dentro de igreja estabelecida, como acontece com a RCC dentro da ICAR - mas de seitas pentecostais (não no sentido vulgar, ofensivo - que tende a diminui-las -, mas no sentido weberiano de um tipo ideal que difere da igreja, no sentido mais preciso). Seria necessário, no entanto, considerar que algumas dessas seitas, as mais tradicionais e antigas no Brasil, tendem a burocratizar-se, passando pelo conhecido processo de "banalização do carisma", como pode estar acontecendo atualmente com a Assembleia de Deus, com pouco mais de um século de existência. Nesse caso, a formação mais recente de pastores em seminários, que os habilitam através de formação teológica mais apurada, bem como a presença nessa igreja (hoje em dia, mais que uma seita) de intelectuais das mais diferentes formaçóes - alguns deles pós-graduados -, pode levar a situaçóes condenatórias do exercício de práticas mágicas e sincréticas nessa igreja (e possivelmente em outras) que podem também levar à ocorrência de fenômenos semelhantes ao que se

13 Sobre isso vale lembrar a estimulante tese de doutorado de Mota (2007) sobre as tensóes na Renovação Carismática em Salvador, que estuda dois grupos de oração (um fundado pelo próprio pároco onde surgiu o grupo e outro, em paróquia diferente, à revelia do pároco) e um núcleo da Comunidade Shalom. Nos dois grupos, o conflito dava-se entre os carismáticos e os párocos. Na comunidade, o conflito se fazia com as famílias dos jovens recrutados pela comunidade, envolvendo até processos judiciais, à maneira como é descrito para a Argentina e a França, onde a RCC pode ser pensada como seita (Frigerio, 1993; Giumbelli, 2002).

Debates do NER, Porto Alegre, ano I5, N. 26, P. I93-227, JUl./DeZ. 20 I4 
observa atualmente na relação entre RCC e ICAR pelo exercício do misticismo e sua crítica por parte de sacerdotes/pastores mais zelosos (Delgado, 2008).

\section{AS APARIÇÕES MARIANAS E A RCC}

O tema das aparições marianas, nos dias atuais - marcado, sobretudo, pelo fenômeno de Medjugorje (1981) na Bósnia-Herzegovina -, tem desdobramentos que indicam nova face assumida pelas mesmas, embora nelas exista também um padrão mais profundo de continuidade. As apariçōes mais antigas, cujos principais modelos são as de Lourdes e Fátima - as mais importantes entre as reconhecidas oficialmente pela ICAR -, às quais se pode também acrescentar La Salette e algumas outras (mas não em tão grande número), obedeciam ao modelo de uma igreja hierárquica em que o leigo tinha papel bastante secundário, diferentemente do que tem ocorrido a partir das grandes mudanças que começaram a ser ensaiadas um pouco antes, mas que foram implantadas mais efetivamente a partir do Concílio Vaticano II.

Uma breve e muito incompleta comparação entre os dois concílios (o Vaticano I e o Vaticano II) e a condição das "duas igrejas" que deles resultaram, prolongando e consolidando tendências que vinham de antes, permitem também refletir sobre o caráter dessas apariçóes. A primeira, ainda fundamentada no modelo Tridentino da Contra Reforma, enfrentando no século XIX uma árdua disputa com diferentes tendências: o liberalismo, impulsionado desde o século anterior pelo iluminismo, pela maçonaria e pelo protestantismo, o que resultou num endurecimento da postura conservadora do governo da ICAR, exacerbada durante o pontificado de Pio IX. Nesse governo, em que ocorreram vários fatos notáveis, entre eles a proclamação dos dogmas da Imaculada Conceição e da Infalibilidade Papal, ao lado da publicação da Encíclica Quanta Cura e do Syllabus Errorum, aconteceu também um fato político da maior importância, seguindo-se aos processos da unificação alemã sob a liderança de Bismarck, da guerra franco-prussiana e da deposição de Luís Bonaparte na França: a complementação do processo de unificação italiana, 
sob a liderança de Cavour e de Garibaldi, que resultou na perda dos Estados Pontifícios e na autodeclaração do papa Pio IX como "prisioneiro do Vaticano"14.

É nesse contexto político que se pode também interpretar as apariçôes de Lourdes, cuja vidente contribuiu favoravelmente para a bandeira ultramontana de Pio IX com a revelação do anúncio de Maria: "Eu sou a Imaculada Conceição". Vários anos depois, na segunda década do século XX, temos as apariçóes de Fátima. $\mathrm{O}$ contexto político é outro, mas a postura conservadora e ultramontana da ICAR se mantém. $\mathrm{O}$ ano das apariçóes de Fátima é significativo: 1917, o mesmo da Revolução Bolchevique. Deixando parcialmente de lado toda a complexidade política e religiosa do evento, que inclui mudanças políticas e devocionais em um Portugal não mais monárquico - pois durante a monarquia as devoçóes a Nossa Senhora de Nazaré e a Nossa Senhora da Conceição tinham grande importância -, a nova devoção de Fátima (depois de oficializada) transforma-se na mais importante desse país, com forte apoio de Roma e, também, durante muitos anos, um símbolo da luta contra o comunismo. Nada disso diminui o caráter místico e a importância religiosa de todas essas devoçôes para os católicos ${ }^{15}$.

${ }_{14}$ Nesses documentos, o Papa - que no início de seu pontificado chegou a ser encarado com simpatia pelos liberais - condenou uma série de posturas liberais, de caráter materialista e mesmo religiosas, como o naturalismo, o racionalismo, o panteísmo, o socialismo, o comunismo, o indiferentismo, o liberalismo, a maçonaria, o judaísmo e diferentes formas de interpretação da Bíblia assumidas por outras igrejas cristãs. A posição política que assumiu, seguida por muitos católicos (leigos, padres e bispos) no mundo inteiro, foi cunhada de ultramontana, denominação criada por liberais franceses (entre os quais católicos que a ela se opunham), já que o Papa governava os Estados Pontifícios, que se situavam na península italiana, "além dos montes", isto é, dos Alpes.

15 É bem conhecido que a devoção a Maria é muito antiga em Portugal, mesmo antes do surgimento da nação portuguesa. D. Afonso Henriques, o fundador da nação e da monarquia portuguesa, colocou seu país sob a proteção de Maria desde 1142. A tradição popular indica também o fortalecimento do culto a Nossa Senhora de Nazaré e, anos mais tarde, após o domínio espanhol e a recuperação da independência de Portugal em 1640, Nossa Senhora da Conceição passa a ser a padroeira desse país e de todas as suas colônias, inclusive o Brasil (que, desde os anos de 1930 passou a ter como padroeira oficial Nossa Senhora da Conceição Aparecida). Mas, ainda na primeira metade do século

Debates do NER, Porto Alegre, ano I5, N. 26, P. I93-227, JUl./DeZ. 20 I4 
As novas apariçóes, tomando parcialmente como "roteiro" o paradigma de Medjugorje - embora esta não tenha sido ainda aprovada oficialmente pela ICAR - caminham num sentido diverso, embora não se possa nelas desprezar também o aspecto político: é que aí já estão presentes as influências do Concílio Vaticano II e, tomando o caso brasileiro como exemplo, a influência da RCC. Neste aspecto, a influência da mística resulta numa inovação, como está bem caracterizado nos termos de Carlos Steil:

Enquanto os agentes oficiais usam a ciência no contexto das apariçóes como uma estratégia de controle interno sobre o evento, os carismáticos vão usá-la, no contexto das apariçóes contemporâneas, em sentido contrário, como mais uma mediação linguística da experiência religiosa [...]. Na comparação entre essas duas estratégias poderíamos dizer que, enquanto o clero em seu posicionamento oficial aciona a ciência para desmistificar as apariçóes de seu sentido extraordinário, num esforço por traduzir a mística numa linguagem teológico-racional, os carismáticos, na tentativa de provar a veracidade do evento, mistificam os procedimentos e recursos da ciência, traduzindo-os numa linguagem simbólica e espiritual (Steil, 2003, p. 33).

Neste ponto, utilizando o conceito de "profecia" tal como proposto pelo antropólogo americano Thomas J. Csordas, como uma formulação em primeira pessoa - a indicar que quem fala não é o profeta, mas o próprio Deus, que o transforma em seu instrumento ${ }^{16}$-, diz ainda Carlos Steil:

XX, com a aparição de Fátima e a maior importância dessa devoção - cujo santuário atrai peregrinos de todo o mundo -, ela se torna, com o apoio de Roma e do governo português, a devoção mais importante de Portugal.

${ }^{16}$ Como exemplo, uma formulação sintética do próprio Thomas Csordas: "I [...] present a phenomenological account of speaking and hearing prophecy and a comparison of prophecy and glossolalia. I suggest that the existential force of prophecy stems from the sense in which all language can be understood as an aspect of bodily experience, which in turn proves to be the ground of all experience of force. As a self process, charisma thus appears to be equally a function of textuality and embodiment". Um pequeno fragmento das chamadas "bulwark prophecies" ajudará a entender o conceito: "I have spoken to 
A profecia aparece, portanto, no contexto carismático e das apariçóes como uma espécie de revelação e um meio de acesso experiencial e imediato à mente e à vontade divinas. Uma intimidade com o sagrado que se manifesta no ritual, mas que também transborda para a vida cotidiana. O que muda, na verdade, é apenas a representação ou nomeação do selfsagrado que predomina em cada um: o Espírito Santo no contexto carismático e Maria entre os devotos das apariçōes. Esta identificação em termos do "gênero ritual", no entanto, é tal, que muitas vezes o Espírito Santo e Maria são confundidos pelos próprios fiéis (Steil, 2003, p. 34-35, grifos do autor).

E aqui, seguindo ainda a reflexão desse mesmo antropólogo, encontramos o que indica ser talvez o aspecto mais importante do fenômeno recente das aparições de Maria, no contexto contemporâneo da globalização, pois nisso encontra-se uma nítida aproximação entre estilos de profecia de carismáticos católicos e videntes de Maria: "Há um duplo mimetismo ocorrendo entre essas duas formas rituais, pelo qual a vidência parece 'evoluir' para a forma das 'locuçóes interiores', nos contextos de aparição". E acrescenta: "[...] ao mesmo tempo em que, nos contextos carismáticos, o self sagrado que fala no interior de seus participantes, comumente representado pelo Espírito Santo, vem sendo com frequência substituído por Maria" (Steil, 2003, p. 36). Encontramos então, nesse contexto, uma diferença que é marcante nas apariçōes contemporâneas, conforme nos informa esse autor, a partir da "literatura recente", da "observação de campo" e dos "comentadores católicos":

Nesse percurso [...] constata-se uma tendência à valorização da "locução interior", em detrimento da vidência, o que corresponde, ao nosso ver, a uma tendência mais geral da religião na condição pós-moderna, que, como observa Otávio Velho, poderia ser pensada como um movimento de "destradicionalização, o qual se identificaria menos com a simples quebra da tradição e mais com a reflexividade" [...]. Observa-se, portanto, um processo pelo qual

you of a bulwark; I have told you that I am raising a bulwark against the coming tide of darkness, a bulwark to protect my people and protect my Church" (Csordas, 1996, p. XVIII, p. 209). 
podemos ver como a dimensão da subjetividade e da reflexividade é incorporada em ambientes tradicionais através de recursos rituais disponibilizados pelas religiōes (Steil, 2003, p. 36) ${ }^{17}$.

É esse encontro entre duas místicas cristãs-católicas que desejo acentuar ao final deste tópico: a mística da RCC e a mística das apariçóes marianas. Dessa conjugação surge algo novo, que vem marcar esses dois fenômenos, fortalecendo-os e dando-lhes maior autonomia. Tudo isso tem a ver com as características do fenômeno religioso na modernidade em que atualmente vivemos, num certo estágio dessa mesma modernidade, que é marcado pela forma como se apresenta, hoje em dia, o fenômeno moderno da mundialização ou globalização, como queiramos chamá-lo. Mas, agora, antes de passar às consideraçóes finais, desejo tratar ainda de outras formas de mística, não necessariamente cristãs-católicas, mas que têm muito a ver com o estágio presente da humanidade e com o estágio atual do fenômeno religioso que, longe de ter alcançado seu final, aponta-nos para novos e surpreendentes desdobramentos.

\section{A MÍSTICA DAS RELIGIŌES DE MATRIZ AFRICANA, DO XAMANISMO URBANO, DAS PLANTAS E DE OUTRAS SUBSTÂNCIAS DE PODER}

Ao longo deste artigo, apresentei elementos ligados à mística, no sentido de um tipo ideal weberiano, aplicados até agora a duas temáticas que tenho investigado como antropólogo: o xamanismo da pajelança cabocla amazônica e um aspecto mais reconhecido do catolicismo, um de seus novos movimentos eclesiais (a RCC), bem como as relações desta última com as características mais recentes das novas apariçóes marianas, especialmente

${ }^{17}$ A citação de Otávio Velho é de um capítulo por ele publicado em livro organizado por Carlos Steil e Ari Pedro Oro (Steil; ORO, 1997). Uma versão anterior do artigo de Otávio Velho foi publicada na revista Mana, podendo ser consultado também on line (Velho, 1997, p. 133-154). 
no Brasil. Devo também acentuar que, numa certa perspectiva, não estive afastado do catolicismo, pelo menos daquele que pode ser rotulado de catolicismo popular, desde que os agentes xamãs da pajelança cabocla e os seus clientes não se pensam praticando outra forma de religião, considerando-se, caso inquiridos, como bons católicos.

Portanto, antes de chegar às consideraçóes finais, pretendo acrescentar ainda algumas reflexóes sobre a mística que está presente nas religióes de matriz africana, no chamado xamanismo urbano e na Nova Era. Aqui nós nos afastamos mais do catolicismo, embora alguns dos participantes dessas práticas não deixem de utilizar o sincretismo com o catolicismo e, mesmo, com o pentecostalismo protestante. Ao lado disso, pretendo também tratar aqui sobre outro aspecto da mística, que está presente em todas essas manifestações religiosas - inclusive no cristianismo -, que diz respeito ao que, num sentido talvez mais ampliado do que se costuma utilizar, penso poder chamar de enteógenos.

O enteógeno, aquilo que ajuda e proporciona mais facilmente a união mística com a divindade, normalmente é pensado como alguma substância ingerida oralmente ou inalada pelo sujeito humano dessa união. Não obstante, sabe-se que, mesmo sem ingerir ou inalar qualquer substância, o êxtase, o transe e a possessão podem ser obtidos por outros meios, como a música instrumental, o canto, a dança, o sexo, ou alguma outra forma eficaz de excitar a emoção. Salvo nos casos em que o êxtase e o transe (neste caso, não podemos falar em possessão) se obtêm sem que haja uma interpretação mística ou religiosa - como numa manifestação coletiva, num espetáculo artístico ou em outra atividade despida da noção de sobrenatural ou de relacionamento íntimo com poderes extra-humanos -, nas outras situaçóes a que me refiro, há algum elemento que pode colocar uma entidade não humana dentro do crente, tomando seu corpo. Isto, com graus variados de consciência ou inconsciência daquele sujeito místico em relação ao processo, mas em contato muito próximo, seja no sentido de sentimento, inspiração, presença, diálogo, companheirismo ou possessão. 
Vários enteógenos ou substâncias "psiquedélicas" (como as denomina Esther J. Langdon, a partir de A. B. Sell) são utilizados em diferentes formas religiosas e cultos, como o peiote, o yagé ou ayahuasca (e outros chás), o tabaco, o incenso (e outros tipos de fumaça), a maconha, a coca, a aguardente e muitas outras ${ }^{18}$. Seria longo tratar de todos os usos, mas gostaria de acrescentar que normalmente não se fala no uso cristão de enteógenos, como o incenso, ou - mais importante ainda - como o pão e o vinho, nas celebraçóes eucarísticas, ingestão ritual que literalmente (com diferenças importantes para católicos e protestantes) coloca o próprio Deus em interação mística com o crente.

Existem registros deste fenômeno místico de interação entre os seres humanos e os deuses no chamado "Ocidente" desde pelo menos os mistérios de Elêusis e do Oráculo de Delfos, na antiga Grécia. Neste último caso, a pitonisa, uma sacerdotisa inspirada, ao aspirar vapores subterrâneos, como é bem conhecido, incorporava o deus Apolo e, através dessa incorporação, podia responder às perguntas de seus consulentes. Nas religiôes de matriz africana, desde pelo menos o sul dos Estados Unidos da América até a Argentina, assim como na própria África, várias formas de manifestações religiosas - incluindo entidades sobrenaturais, música, dança, canto e diferentes tipos de ritual, assim como comidas e bebidas sagradas - proporcionam as unióes místicas, descritas numa abundante literatura, mas também proporcionam a elaboração de textos poéticos compondo cantos que, na análise de José Jorge de Carvalho, mostram a sofisticação de seus textos, expondo a "tradição mística afro-brasileira" e "o misticismo dos espíritos marginais", para ficar somente nesses dois exemplos (Carvalho, 1998; 2001).

É também possível interpretar a sociedade brasileira, como o fez Reginaldo Prandi, a partir de uma análise dos terreiros de religióes de

18 A bibliografia é muito vasta. Entre os vários trabalhos consultados cito somente alguns (Csordas, 2008; Langdon, 2005; Lanternari, 1974; Monteiro da Silva, 2002; Taussing, 1991). Dois livros de referência no Brasil são as coletâneas organizadas por Labate e Araujo (2002) e Labate e Goulart (2005), nas quais se encontram dois dos textos acima citados. 
matriz africana (Prandi, 2008). Assim como, considerando a relação entre catolicismo oficial e as várias formas de religiosidade popular, pode-se também entender melhor o Brasil relacionando o culto de Maria a Oxum e a Iemanjá, nas suas diversas expressōes, mas especialmente o culto da Virgem Negra - Nossa Senhora (da Conceição) Aparecida, a padroeira do Brasil -, como o fez Rubem César Fernandes em um de seus artigos mais conhecidos (Fernandes, 1988).

\section{CONSIDERAÇÕES FINAIS: XAMANISMO URBANO, NOVA ERA, SECULARIZAÇÃO E PÓS-MODERNIDADE}

E, para concluir, faço agora breve referência ao xamanismo urbano e à nova era, temas que são tratados por vários autores, no Brasil. Limito-me porém a mencionar aqui somente alguns, entre vários outros, que tratam do tema (Magnani, 1999; Amaral, 2000; Soares, 1994; Carneiro, 2003; Steil; Carneiro, 2008). A escolha é aleatória e se prende mais aos meus interesses atuais de leitura. Não comentarei propriamente esses autores, pois desejo enfocar mais propriamente dois estudos recentes realizados na Amazônia - que em parte se fundamentam nesses mesmos autores - sobre duas mulheres que são xamãs de maior notoriedade nesta região brasileira. Uma delas - e a mais conhecida - já foi mencionada anteriormente: dona Zeneida Lima. A outra, menos conhecida, é dona Roseana Gil, falecida há poucos anos. Ambas foram objeto de trabalhos acadêmicos recentes: uma dissertação de mestrado em ciência da religiāo (Faro, 2012) e outra de tese de doutorado em antropologia (Villacorta, 2011) ${ }^{19}$.

O trabalho de Mayra Faro não aborda somente dona Zeneida Lima, mas também outros pajés da ilha do Marajó, no estado do Pará, a maior ilha flúvio-marítima do mundo, que se encontra à margem direita do

19 Registro também programa de televisão recentemente exibido pela Globo News, em que o político e hoje apresentador da Globo Fernando Gabeira faz interessante entrevista com Zeneida Lima (transmitido em 15/12/2013 e dias subsequentes).

Debates do NER, Porto Alegre, ano I5, N. 26, P. I93-227, JUl./DeZ. 20 I4 
rio Amazonas, em sua embocadura. Não obstante, devido à importância de Zeneida nessa prática e também ao seu renome, que vai bem além da Amazônia, a autora dá importância especial a essa xamã. Um pequeno trecho de sua tese pode nos dar a conhecer parte dessa dimensão:

Os livros de Zeneida Lima sobre pajelança, o desfile da escola de samba BeijaFlor no carnaval de 1998, o filme "Amazônia Caruana" ${ }^{20}$ em vias de estreia no cinema brasileiro, e a novela "Amor eterno amor" (que teve cenas filmadas na região e que foi exibida na rede Globo em meados de 2012), são fatores que lançam ao mundo o Marajó e sua cultura, ou o que acreditam ser essa cultura. Em quase todos esses fatores a figura de Zeneida Lima está presente. Não é errado pensar que ela é responsável em grande parte por essa visibilidade do Marajó para o mundo. Ela lançou e continua a lançar uma imagem de Soure e sua cultura que não necessariamente corresponde à realidade, mas que ao mesmo tempo desempenha um papel importante na cidade com a escola que hoje leva seu nome (Faro, 2012, p. 32).

Provavelmente por esses motivos é que Zeneida adquire a importância que tem, não obstante as acusações (falsas, evidentemente) de que é vítima, entre as quais a de ser "feiticeira". Não é incomum que pajés amazônicos (xamãs em geral) sejam pensados como feiticeiros, no sentido de pessoas que provocam o mal, utilizando-se de seus poderes. Como qualquer curador (healer, para usar a expressão inglesa), a ideia é implícita, pois aquele que sabe curar sabe também provocar danos à saúde. Na maioria dos casos, porém, essa falsa acusação de feitiçaria aplica-se mais às mulheres do que aos homens. Citando a dissertação de mestrado da antropóloga Gisela

${ }^{20}$ O filme (longa metragem) está previsto para ser lançado em 2013 e se baseia no principal livro escrito por essa xamã, direção de Tizuka Yamasaki. Aparentemente está pronto, mas mudou de nome. Chama-se agora Encantados. Uma espécie de trailer está disponível na internet pelo link: http://www.google.com.br/url?sa=t\&rct=j\&q=amazonia\%20caruana\%20filme\&source $=$ web \&cd $=2 \& \mathrm{cad}=$ rja\&ved=0CEAQtwIwAQ\&url=http $\% 3 \mathrm{~A} \% 2 \mathrm{~F} \% 2 \mathrm{Fvimeo}$. com\%2F49380816\&ei=6GoCUpdHh9L2BKmsgMAJ\&usg=AFQjCNGWRTeDPjDmltCFh3h5PE32wNS2MA. Acesso em 07 ago. 2013. 
Macambira Villacorta (Villacorta, 2000), Mayra Faro coloca essa questão para um contexto específico amazônico, a ilha e a cidade de Colares, mas que se aplica também a várias outras áreas dessa região:

No município de Colares [...] mesmo sendo limitado o exercício do gênero feminino na pajelança, havia mulheres pajés. Porém, elas eram discriminadas por parte da sociedade e chamadas de Matinta-Perera, feiticeiras do imaginário amazônico que, segundo a autora, mescla elementos mitológicos da cultura africana (as "mulheres do pássaro da noite"), pré-judaica (Lilith) e do cristianismo medieval (a bruxa). Acredita-se que a matinta é uma mulher ora de aparência idosa e feia, ora jovem e bela, que carrega consigo um fado, herdado de família (de avó para neta), e que se contrariada ou desrespeitada pode lançar um feitiço, doença ou desgraça para um indivíduo. Anda sempre acompanhada de um pássaro, que com seu assobio anuncia a presença da bruxa (Faro, 2012, p. 53).

Mais do que isso, porém, Zeneida Lima é ainda influenciada pela nova era, como reafirma Mayra Faro e como também aparece nos trabalhos da antropóloga Gisela Macambira Villacorta citados por ela. Entretanto, mesmo que esta antropóloga também dê atenção a Zeneida Lima em seus estudos, a figura emblemática de dona Roseana Gil é a personagem principal desta antropóloga (Villacorta, 2000; 2011). Como ela mesma coloca, em artigo recente:

Este texto [...] teve como principal propósito traçar o perfil de uma personagem que tem importância decisiva em minha formação antropológica: Roseana Gil, xamá a quem retratei em vários de meus trabalhos acadêmicos. Para mim, tal personagem teve importância tão destacada quanto determinados interlocutores [...] famosos de alguns antropólogos clássicos como Muchona, a Vespa, no caso de Victor Turner; Pa Fenutara, um aristocrata Tikopia, no caso de Raymond Firth; Maling, uma menina Hanunóo das Filipinas, no caso de Harold C. Conklin; ou Champukwi, da aldeia das antas (Brasil), no caso de Charles Wagley (Villacorta, 2012, p. 187). 
Dona Roseana, ou Rose, foi descoberta por Villacorta na ilha e cidade paraense de Colares, na região do Salgado (cujo nome deriva de sua localização junto ao Atlântico). Ela não era nativa do lugar, mas considerava-se uma pajé (praticando, como dizia, a "pajelança cabocla”, termo que aprendeu pela leitura da obra de Eduardo Galvão). Tratava-se na verdade de uma espécie de xamã urbana, que adotava várias práticas rituais, sendo também muito influenciada por práticas e concepções da nova era, tendo morado por algum tempo em Belo Horizonte, onde frequentou (depois de atuar em Colares) o que dizia ser uma "faculdade holística". Tinha conhecimento de vários autores, inclusive de antropólogos bem conhecidos, além de Galvão, entre os quais Michael Harner e Carlos Castañeda, assim como místicos e esotéricos como "mestre Saint Germain", intitulando-se como praticante do neoxamanismo, além de adotar o título e o nome de "xamã Rosa Azul".

Essas duas místicas amazônicas - dona Zeneida Lima e dona Roseana Gil - representam muito bem aspectos fundamentais da religião na pós-modernidade, na medida em que unem numa bricolage bem conduzida elementos variados do cristianismo, do xamanismo indígena e caboclo, da nova era e de várias outras influências. Zeneida Lima recebeu influências, por exemplo, de Nunes Pereira e da Casa das Minas, no Maranhão, quando era bem jovem (embora em seu livro autobiográfico isto não apareça). Enquanto Roseana Gil, a partir de suas leituras e vivências, apresenta também marcada influência do romantismo e indigenismo brasileiro (uma de suas narrativas sobre "vidas passadas" reproduz parcialmente o clássico relato da índia Iracema, de José de Alencar, que encontramos também em outros mitos de mulheres indígenas no Brasil e nos EUA). Claramente, podemos pensar aqui que, a despeito de todos os avanços reais da secularização, de outro lado e paralelamente, o mundo - pelo menos entre nós, mas provavelmente não somente entre nós, amazônidas, brasileiros e latino-americanos - vai se secularizando cada vez mais. Porém, ao mesmo tempo, ao contrário do que se chegou a pensar alhures, não perde seu encantamento. Porque as duas dimensóes, do encantamento e do desencantamento (juntamente com a secularização), podem certamente conviver simultaneamente em nossa contemporaneidade pós-moderna. 


\section{REFERENCIAS}

ALMEIDA PINTO, Antônio Rodrigues de. O Bispado do Pará. Annaes da Bibliotheca e Archivo Público do Pará. Tomo V. Belém: Typ. e Encadernação do Instituto Lauro Sodré, 1906, p. 11-191.

AMARAL LAPA, José Roberto do. Livro da Visitação do Santo Ofício da Inquisição ao Estado do Grão-Pará (1763-1769). Texto inédito e apresentação de J. R. Amaral Lapa. Petrópolis: Ed. Vozes, 1978.

AMARAL, Leila. Carnaval da Alma: Comunidade, Essência e Sincretismo na Nova Era. Petrópolis: Vozes, 2000.

BAPTISTA, Selma. Glossolalia: O sentido da desordem. A simbologia do som na constituição do discurso pentecostal. Dissertação (Mestrado em Antropologia Social). Campinas: Instituto de Filosofia e Ciências Humanas, UNICAMP, 1989.

BONFIM, Evandro. A Canção Nova: Circulação de dons, mensagens e pessoas espirituais em uma comunidade carismática. Tese (Doutorado em Antropologia Social). Rio de Janeiro: Programa de Pós-Graduação em Antropologia Social, UFRJ/Museu Nacional, 2012.

BOURDIEU, Pierre. A Economia das Trocas Simbólicas. São Paulo: Perspectiva, 1974.

CARNEIRO, Sandra Maria de Sá. Em Rumo a Santiago de Compostela: os sentidos de uma peregrinação moderna. Tese (Doutorado em Antropologia Social). Rio de Janeiro: Programa de Pós-Graduação em Sociologia e Antropologia/ PPGSA, Universidade Federal do Rio de Janeiro, 2003.

CARRANZA, Brenda. Renovação Carismática Católica: Origens, mudanças e tendências. Aparecida: Editora Santuário, 2000.

CARRANZA, Brenda; MARIZ, Cecília; CAMURÇA, Marcelo. Novas Comunidades Católicas: Em busca do espaço pós-moderno. Aparecida: Editora Ideias e Letras, 2009. 
CARVALHO, José Jorge. A Tradição Mística Afro-Brasileira. Religiāo e Sociedade. n.18. v.2, 1998. Disponível em: http://pt.scribd.com/ doc/60299892/A-Tradicao-Mistica-Afro-Brasileira. Acesso: 18 mar. 2013. . El Misticismo de los Espíritus Marginales. Marburg Journal of Religion. n.6. v.2. June 2001. Disponível em: http://www.uni-marburg.de/ fb03/ivk/mjr/pdfs/2001/articles/carvalho2001.pdf. Acesso: 18 mar. 2013. CAVALCANTE, Patrícia Carvalho. De "nascença" ou de "simpatia": iniciação, hierarquia e atribuições os mestres na pajelança marajoara. 2008. Dissertação (Mestrado em Antropologia da Religião) - Universidade Federal do Pará, Belém, 2008.

CORTEN, André. Os Pobres e o Espírito Santo: O pentecostalismo no Brasil. Petrópolis: Vozes, 1996.

CSORDAS, Thomas J. The Sacred Self: A cultural phenomenology of Charismatic healing. Berkley, Los Angeles, London: University of California Press, 1994.

. Language. Charisma, and Creativity: The ritual life of a religious movement. Berkeley: University of California Press, 1996.

- Cura Ritual e a Política de identidade na Sociedade Navajo Contemporânea. In: . Corpo/Significado/Cura. Porto Alegre: Editora da UFRGS, 2008. p. 223-257.

DELGADO, Jaime Silva. Nem Terno Nem Gravata: As mudanças na identidade pentecostal assembleiana. Dissertação (Mestrado em Ciências Sociais - Sociologia). Belém: Universidade Federal do Pará, 2008.

ELIADE, Mircea. O Xamanismo e as técnicas arcaicas do êxtase. São Paulo: Martins Fonte, 1998.

FARO, Mayra Cristina Silva. Mulher e pajelança: Um estudo de caso em Soure, na ilha do Marajó/PA. Ciências da Religião História e Sociedade. n. 10. v.2, p. 11-40, 2012a. 
. A cura que vem do fundo: mulher e pajelança em Soure (Ilha do Marajó/PA). Dissertação (Mestrado em Ciências da Religião). Belém: Universidade do Estado do Pará, 2012b.

FERNANDES, Rubem César. Aparecida: nossa rainha, senhora e mãe, saravá! In: FERNANDES, Rubem César; DAMATTA, Roberto et al. Brasil \& EUA: Religião e Identidade Nacional. Rio de Janeiro: Graal, 1988. p. 85-109.

FRIGERIO, Alejandro. La invasión de las Sectas: El debate sobre Nuevos Movimientos Religiosos en los Medios de Comunicación en Argentina, Sociedad y Religión. n. 10/11, p. 32-69, 1993.

GALVÃO, Eduardo. Santos e Visagens: um estudo da vida religiosa de Itá, Baixo Amazonas. São Paulo: Ed. Nacional, 1955.

GIUMBELLI, Emerson. O Fim da Religiāo: Dilemas da liberdade religiosa no Brasil e na França. São Paulo: Attar Editorial, 2002.

LABATE, Beatriz Caiubi; ARAUJO, Wladimyr Sena (Orgs.). O Uso Ritual da Ayahuasca. Campinas: Mercado de Letras, 2002.

LABATE, Beatriz Caiubi; GOULART, Sandra Lúcia (Orgs.). O Uso Ritual das Plantas de Poder. Campinas: Mercado de Letras, 2005.

LANGDON, Esther Jean. Prefácio. In: LABATE, Beatriz Caiubi; GOULART, Sandra Lúcia (Orgs.). O Uso Ritual das Plantas de Poder. Campinas: Mercado de Letras, 2005. p. 13-28.

LANTERNARI, Vittorio. O Peiotismo; Outros Movimentos Proféticos Americanos. In: - As Religióes dos OPRIMIDOS: Um estudo dos modernos cultos messiânicos. São Paulo: Perspectiva, 1974. p. 73-210.

LEWIS, Ioan M. Êxtase religioso: Um estudo antropológico da possessão por espírito e do xamanismo. São Paulo: Perspectiva, 1977.

LIMA, Zeneida. O Mundo Mistico dos Caruanas da Ilha do Marajó. 6. ed. Belém: Cejup, 2002. 
MAGNANI, José Guilherme Cantor. O Circuito Neo-Esotérico na Cidade de São Paulo. In: CAROZZI, M. Julia (Org.). A Nova Era no Mercosul. Petrópolis: Vozes, 1999.

. O Xamanismo Urbano e a Religiosidade Contemporânea. Religião e Sociedade. n. 20. v. 2, p. 113-140, 1999a.

MALLIMACI, Fortunato. Ernest Troelstch y la Sociología Histórica del Cristianismo. Sociedad y Religión 4, p. 1-22, 1987 (CdRom).

MONTEIRO DA SILVA, Clodomir. O uso ritual da ayahuasca e o reencontro de duas tradições. A miração e a incorporação no culto do Santo Daime. In: LABATE, Beatriz Caiubi; ARAUJO, Wladimyr Sena (Orgs.). $O$ Uso Ritual da Ayahuasca. Campinas: Mercado de Letras, 2002. p. 367-398. MOTA, Clarice Santos. Entre a obediência e a subversão: um estudo sobre as tensões na Renovação Carismática Católica. Tese (Doutorado em Ciências Sociais/Antropologia). Salvador: Universidade Federal da Bahia, 2007.

NICOLAU, Roseane Freitas. Um "Novo Católico": Cura, emoção e reconstrução de identidades na Renovação Carismática Católica. Tese (Doutorado em Sociologia). Fortaleza: Universidade Federal do Ceará, 2005.

POLLAK-ELTZ, Angelina. Glosolalia - hablar en lenguas. Presencia ecumenica, n. 38, p. 80-84, 1999.

PRANDI, Reginaldo. A dança dos caboclos: Uma síntese do Brasil segundo os terreiros afro-brasileiros. In: MAUÉS, Raymundo. Heraldo; G. M. VILLACORTA. Pajelanças e Religioes Africanas na Amazônia. Belém: EdUFPA, 2008. p. 31-50.

QUEIROZ, D. Frei João de São José e. Visitas Pastorais (Memoriais 1761, 1762 e 1763). Rio de Janeiro: Melso, 1961.

RAMOS, D. Alberto Gaudêncio. Cronologia Eclesiástica da Amazônia. Manaus: Tipografia Fênix, 1952. 
SOARES, Luiz Eduardo. Religioso por natureza: cultura alternativa e misticismo ecológico no Brasil. In: SOARES, Luiz Eduardo. O rigor da indisciplina. Rio de Janeiro: Relume-Dumará, 1994.

STEIL, Carlos Alberto. As aparições marianas na história recente do catolicismo. In: STEIL, Carlos Alberto; C. L. MARIZ; M. L. REESINK (Orgs.). Maria entre os vivos: Reflexōes teóricas e etnografias sobre aparições marianas no Brasil. Porto Alegre: Editora da UFRGS, 2003. p. 19-36.

STEIL, Carlos Alberto; ORO, Ari Pedro. Globalização e Religião. Petrópolis: Vozes, 1997.

STEIL, Carlos Alberto; CARNEIRO, Sandra de Sá. Peregrinação, Turismo e Nova Era: Caminhos de Santiago de Compostela no Brasil. Religiāo e Sociedade. n. 28. v. 1, p. 105-124, 2008.

TAUSSING, Michael. Shamanism, Colonialism, and the Wild Man. Chicago and London: The University of Chicago Press, 1991.

TEREZA DE JESÚS, Santa. La Vida. In: TEREZA DE JESUS, S.. La Vida, Las Moradas. Clásicos Españoles. PML Editiones, 1955.

TURNER, Victor W. O Processo Ritual: Estrutura e Antiestrutura. Petrópolis: Vozes, 1974.

VÁRGUEZ PASOS, Luis A. Los sacerdotes del movimiento de Renovación Carismática en El Espírito Santo. ¿Brujos, magos o hechiceros profesionales? Ciencias Sociales y Religión/Ciências Sociais e Religião 4, p. 55-85, 2002. Disponível em: http://seer.ufrgs.br/index.php/CienciasSociaiseReligiao/ article/view/2246/951. Acesso em: 17 mar. 2013.

VELHO, Otávio. Globalização: antropologia e religião. Mana. n. 3. v. 1, p. 133-154, 1997.

VILLACORTA, Gisela Macambira. As Mulheres do Pássaro da Noite: pajelança e feitiçaria na região do Salgado (nordeste do Pará). Dissertação (Mestrado em Antropologia). Belém: Universidade Federal do Pará, 2000. 
. Rosa azul: uma xamã na metrópole da Amazônia. Tese (Doutorado em Ciências Sociais/Antropologia). Belém: Universidade Federal do Pará/ UFPA, 2011.

. Rosa Azul: uma xamã urbana na metrópole da Amazônia. In: MAUÉS, R. Heraldo; MACIEL, Maria Eunice (Orgs.). Diálogos Antropológicos: Diversidades, patrimônios, memórias. Belém: L \& A Editora, 2012.

WEBER, Max. A Ética Protestante e o "Espírito" do Capitalismo; tradução de José Marcos Mariani; revisão técnica, edição de texto, apresentação de glossário, correspondência vocabular e índice remissivo por Antônio Flávio Pierucci. São Paulo: Companhia das Letras, 2004. 10ª reimpressão.

. Sociologia da religião (tipos de relações comunitárias religiosas). In: WEBER, Max. Economia e Sociedade. Brasília: Editora da UnB, vol. 1, p. $279-418$.

Recebido em: 17/12/2013

Aceito em: 10/01/2014 